\title{
ANALISA POLA PENENTUAN HARGA PERKIRAAN SENDIRI (HPS) UNTUK PROSES PENGADAAN BARANG DAN JASA PEMELIHARAAN PREVENTIF PENYULANGAN 20 KV DI PT. PLN (PERSERO) AREA AMBON
}

\author{
J. M. Tupan \\ Dosen Program Studi Teknik Industri, Fakultas Teknik Universitas Pattimura, Ambon \\ D. R. Suryanto \\ PLN Wilayah Maluku dan Maluku Utara, Ambon
}

\begin{abstract}
ABSTRAK
Harga Perkiraan Sendiri (HPS) mempunyai peranan penting dalam proses pengadaan sebagai dasar/patokan dari suatu pelelangan. Harga Perkiraan Sendiri harus terus diperbarui sesuai dengan perkembangan ekonomi yang terus berubah di dalam pasar. Dalam proses menemukan Pola Penentuan Harga Perkiraan Sendiri (HPS) ini dilakukan dengan meminta data dari calon penyedia jasa maupun calon penyedia barang berupa data waktu pelaksanaan suatu pekerjaan untuk dijadikan harga satuan jasa dan referensi harga barang untuk dijadikan harga satuan barang. Penelitian yang dilakukan di di PT. PLN (Persero) Area Ambon menyajikan hasil berupa HPS yang dapat dipertanggungjawabkan dengan memperhitungkan tingkat kesulitan pekerjaan, misalnya pekerjaan pemasangan tiang besi 156 dan untuk daerah normal adalah sebesar Rp 436.969,00 sedangkan untuk pemasangan di daerah yang sulit sebesar Rp 546.211,00
\end{abstract}

Kata kunci: PT. PLN (Persero), Pengadaan Barang dan Jasa, Harga Perkiraan Sendiri (HPS)

\begin{abstract}
"Harga Perkirraan Sendiri" (HPS) or Self-Estimated Price in the procurement process has an important role as the basis/benchmark of an auction. The HPS is always updated following the changing economic developments in the market. It is determined by requesting data from prospective service providers and prospective suppliers of goods i.e. data on the time of the execution of a job to be used as a unit price of services and a reference for the price of goods to be used as unit price of goods. A research that conducted in PT. PLN (Persero) Area Ambon provides a HPS that can be accounted for by taking into account the level of difficulty of work, for example the work of installing 156 steel poles and for normal areas is $R p$ 436,969.00 while for installation in difficult areas is $R p$ 546,211.00.
\end{abstract}

Keywords: Procurement of goods and services, Self-Estimated Price, PT. PLN (Persero) Area Ambon.

\section{PENDAHULUAN}

Pengadaan barang/jasa menduduki posisi yang sangat penting dalam suatu perusahaan, karena merupakan sarana penggunaan anggaran dalam jumlah signifikan guna mendapatkan barang, jasa, dan pekerjaan yang dibutuhkan perusahaan dalam Penyediaan infrastruktur ketenagalistrikan yang dilakukan oleh PT PLN (Persero) khususnya PT. PLN (Persero) Wilayah Maluku dan Maluku Utara Area Ambon.

Akan tetapi dalam proses pengadaan barang dan jasa tidak selalu berjalan dengan lancar sehingga proses pengadaan barang tersebut bisa dinyatakan gagal dan harus dilakukan pengadaan ulang. Banyaknya Pengadaan gagal membuat kinerja PT. PLN (Persero) Area Ambon di bagian penyerapan anggaran sangat rendah dan berdampak pula pada kinerja korporat secara keseluruhan. Misalnya saja di tahun 2016 Sendiri terdapat beberapa paket kontrak pekerjaan pemeliharaan preventi penyulang $20 \mathrm{kV}$ yang gagal lelang. Dari 12 Paket pengadaan pemeliharaan preventif pada penyulang $20 \mathrm{KV}$ di semua wilayah kerja PT. PLN (Persero) Area Ambon ternyata hanya 2 paket pemeliharaan saja yang berhasil terkontrak. Selain berdampak pada kinerja penyerapan anggaran yang kecil gagal lelang juga berdampak pada tidak terlaksananya pemeliharaan penyulang $20 \mathrm{kV}$ yang mana pekerjaan ini sangat penting mengingat di PT. PLN (persero) sendiri masih sering terjadi pemadaman yang diakibatkan baik oleh faktor alam maupun dari peralatan-peralatan PLN itu sendiri. Oleh karena itu proses pengadaan barang dan jasa khususnya pemeliharaan preventif penyulang $20 \mathrm{kV}$ diusahakan dapat terlaksana dengan baik mengingat pentingnya pekerjaan tersebut untuk kinerja PT. PLN (Persero) Area Ambon. Dalam Proses 
pengadaan barang dan jasa Harga Perkiraan Sendiri (HPS) mempunyai peranan yang sangat penting dalam proses pengadaan barang dan jasa di karenakan Harga Perkiraan Sendiri (HPS) adalah dasar/patokan dari suatu pelelangan. Harga Perkiraan Sendiri (HPS) yang terlalu rendah akan berdampak resiko kegagalan lelang semakin besar dan juga sebaliknya apabila Harga Perkiraan Sendiri (HPS) terlalu tinggi maka akan mengakibatkan pemborosan anggaran dan mengakibatkan kerugian bagi perusahaan. Maka dari itu HPS yang dibuat oleh pejabat pelaksana pengadaan harus disusun dengan cermat, diperbarui sesuai dengan perkembangan ekonomi yang terus berubah di dalam masyarakat, disesuaikan dengan kondisi lapangan yang ada sehingga dapat menguntungkan kedua belah pihak baik PLN sebagai pengguna barang/jasa maupun para rekanan (vendor) sebagai calon penyedia barang dan jaas guna kelancaran proses pengadaan tersebut. Penelitian ini bertujuan untuk mendapatkan metode dalam penetapan Harga Perkiraan Sendiri (HPS) dan untuk mendapatkan Harga Perkiraan Sendiri (HPS) yang sesuai dalam proses pengadaan barang dan jasa pemeliharaan preventiv penyulang $20 \mathrm{kV}$.

\section{LANDASAN TEORI}

\section{Pengertian Pengadaan Barang/Jasa}

Pengadaan barang dan jasa adalah Proses untuk mendapatkan barang / jasa dengan kemungkinan pengeluaran terbaik, dalam kualitas dan kuantitas yang tepat, waktu dan tempat yang tepat untuk menghasilkan keuntungan atau kegunaan secara langsung bagi pemerintah, perusahaan atau pribadi yang dilakukan melalui kontrak.

\section{Harga Perkiraan Sendiri}

Harga Perkiraan Sendiri (HPS) adalah perhitungan harga perkiraan dari suatu barang/jasa yang dihitung berdasarkan estimasi biaya pokok produksi atau estimasi biaya pokok pekerjaan yang disesuaikan dengan kondisi ekonomi terkini dan faktor-faktor lain yang berfungsi untuk melihat kewajaran harga penawaran (Purwanto, 2017). Harga Perkiraan Sendiri (HPS) disusun berdasarkan Dokumen Rencana Pengadaan dan Dokumen Pelelangan/RKS. HPS merupakan alat untuk melihat kewajaran harga penawaran dan tidak wajib diumumkan serta tidak dapat dijadikan dasar sebagai satusatunya penggugur penawaran. HPS itu sendiri dibuat oleh Pejabat Pelaksana Pengadaan dan disahkan oleh Pengguna Barang/Jasa. HPS disusun secara cermat dan profesional dengan menggunakan data/referensi, antara lain

1. Harga Perkiraan Engineering (HPE).

2. Dokumen Pelelangan (Spesifikasi/Rencana Kerja dan Syarat-syarat (RKS)/Kerangka Acuan Kerja (KAK) atau Term Of Reference (TOR) atau Syarat Penawaran/ Syarat Perjanjian/Kontrak).

3. Harga pasar setempat.

4. Harga Perjanjian/Kontrak untuk barang atau pekerjaan sejenis yang sedang atau telah dilaksanakan.

5. Analisa harga satuan pekerjaan.

6. Daftar harga dan tarif dari instansi yang berwenang.

7. Informasi yang dipublikasikan secara resmi oleh Badan Pusat Statistik (BPS) atau media cetak dan elektronik lainnya atau instansi yang berwenang.

8. Daftar harga/tarif barang/jasa yang dikeluarkan oleh asosiasi pabrikan/agen tunggal atau instansi lain yang berwenang, baik pusat maupun daerah.

9. Untuk barang yang mengandung unsur komponen impor diperhitungkan antara lain fluktuasi nilai tukar mata uang asing dari negara asal terhadap Rupiah dan/atau LME (London Metal Exchange) rate dan/atau Harga Minyak Dunia serta bea masuk.

Harga Perkiraan Sendiri (HPS) yang disusun oleh pejabat Pelaksana Pengadaan wajib memperhatikan hal-hal sebagai berikut:

1. Pajak Pertambahan Nilai (PPN) dan bea masuk sesuai dengan peraturan perundang-undangan yang berlaku.

2. Risiko, Overhead Cost dan Keuntungan (ROK) yang wajar bagi Penyedia Barang/Jasa, sesuai dengan tingkat kesulitan pekerjaan yang dilakukan dan besarnya risiko, yang besarnya maksimum 10\% (sepuluh persen), kecuali ditentukan lain oleh Pengguna Barang/Jasa berdasarkan rekomendasi Value for Money Committee.

3. Dalam hal HPE sudah memperhitungkan ROK, maka HPS tidak lagi memasukan unsur ROK.

4. HPS tidak boleh memasukan biaya tak terduga (contingency), biaya lain-lain dan Pajak Penghasilan $(\mathrm{PPh})$. 
Nilai dari Harga Perkiraan Sendiri (HPS) boleh sama dengan Harga Perkiraan Engineering (HPE) yang disusun oleh pejabat Perencana Pengadaan tetapi tidak boleh melebihi pagu anggaran yaitu besarnya alokasi dana yang diberikan oleh perusahaan untuk proses pengadaan barang/ jasa tertentu.

Untuk Pekerjaan Jasa Konsultasi, Harga Perkiraan Sendiri yang dibuat oleh pejabat pelaksana Pengadaan Wajib memperhitungkan hal-hal sebagai berikut:

1. Mempelajari dan memahami Kerangka Acuan Kerja (KAK)/Terms of Reference (TOR) termasuk syarat Perjanjian/Kontrak

2. Mempelajari dan mengumpulkan informasi/data-data mengenai kondisi lapangan.

3. Mempelajari program dan jadwal pelaksanaan pekerjaan.

4. Menetapkan jumlah kualifikasi tenaga ahli, tenaga teknis serta tenaga pendukung lainnya termasuk jadwal penugasan masing-masing personil, fasilitas/peralatan yang diperlukan dan lain-lain.

5. Mempelajari dan mempertimbangkan ketentuan ketentuan yang dikeluarkan oleh Instansi yang berwenang.

6. Menghitung Biaya Langsung Personil (remuneration) dan Biaya Langsung Non Personil (direct cost).

1) Biaya Langsung Personil meliputi pembayaran, teknisi dan tenaga penunjang. Biaya langsung personil bagi masing-masing tenaga ahli dihitung berdasarkan satuan waktu tertentu (bulan, minggu, hari, jam) dikaitkan dengan rate yang berdasarkan harga pasar dan/atau berdasarkan gaji dasar dan/atau Perjanjian/Kontrak yang lalu/sedang berjalan sesuai dengan tahun pengalaman profesional yang ditetapkan dalam KAK/TOR, dan

2) Biaya Langsung Non Personil meliputi segala biaya yang langsung berkaitan menunjang pelaksanaan tugas konsultan, antara lain pengadaan/sewa kantor, sewa kendaraan, sewa rumah, biaya perjalanan dinas, biaya pelaporan, biaya komunikasi dan lain-lain, dengan mengacu kepada rate/tarif harga pasar setempat dan/atau tarif/harga satuan Perjanjian/Kontrak yang lalu/sedang berjalan. (PT.PLN (Pesero).0620.K/DIR/2013)

\section{Pengukuran Waktu Kerja}

Waktu merupakan elemen yang sangat menentukan dalam merancang atau memperbaiki suatu sistem kerja. Peningkatan efisiensi suatu sistem kerja mutlak 3 berhubungan dengan waktu kerja yang digunakan dalam berproduksi. Pengukuran waktu (time study) pada dasarnya merupakan suatu usaha untuk menentukan lamanya waktu kerja yang dibutuhkkan oleh seorang operator (yang sudah terlatih) untuk menyelesaikan suatu pekerjaan yang spesifik, pada tingkat kecepatan kerja yang normal,serta dalam lingkungan kerja yang terbaik pada saat itu. Dengan demikian pengukuran waktu ini merupakan suatu proses kuatitatif, yang diarahkan untuk mendapatkan suatukriteria yang obyektif. Study mengenai pengukuran waktu kerja dilakukan untuk dapat melakukan perancangan atau perbaikan dari suatu sistem kerja. Untuk keperluan tersebut, dilakukan penentuan waktu baku, yaitu waktu yang diperlukan dalam bekerja dengan telah mempertimbangkan faktor-faktor diluar elemen pekerjaan yang dilakukan (Sutalaksana, dkk, 2006).

Secara umum, teknik-teknik pengukuran waktu kerja dapat diperoleh dengan cara sebagai berikut:

1. Pengukuran waktu dengan jam henti (Stop Watch Jam ), Karakteristik sistem kerja yang sesuai :

1) Jenis aktivitas pekerjaan bersifat homogen

2) Aktivitas dilakukan secara berulang - ulang dan sejenis

3) Umumnya mengamati satu orang

4) Siklus Pekerjaan Pendek dan Jelas.

Berikut adalah Langkah - langkah pengukuran waktu kerja dengan jam henti :

A. Lakukan identifitas pekerjaan yang akan diamati dan diukur waktunya dan deskripsikan maksud dan tujuan kepada seluruh pendukung sistem kerja yang diamati.

B. Kumpulkan semua informasi mengenai proses yang dilakukan pada obyek pengamatan seteliti mungkin

C. Uraikan pekerjaan dalam elemen - elemen aktivitas kerja yang lebih kecil untuk memudahkan pengukuran.

D. Tetapkan tating performansi operator setiap elemen pekerjaan yang dilakukan operator.

E. Lakukan pengukuran waktu kerja setiap elemen pekerjaan yang dilakukan operator.

F. Lakukan pengukuran sejumlah yang diperlukan (dengan menggunakan uji kecukupan data dan uji keseragaman data)

G. Tetapkan faktor penyesuaian dan faktor kelonggaran

H. Tetapkan waktu baku dan sistem kerja yang diamati 
Dalam menentukan pengukuran waktu dengan dalam Pengukuran Waktu Kerja Dengan Jam Henti terdapat beberapa asumsi dasar yang perlu diperhatikan adalah sebagai berikut :

1) Operator yang diamati memahami dan dapat melaksanakan prosedur dan pelaksanaan pekerjaan dengan baik (memiliki kemampuan dan ketrampilan standart )

2) Teknik dan metode yang dilakukan dalam sistem pekerjaan yang diamati harus baku dan standart

3) Kinerja sistem mampu dikendalikan untuk setiap periode kerja vang disediakan

4) Lingkungan pendukung sistem kerja standart, tidak jauh berbeda dengan saat dilakukan pengukuran.

2. $\quad$ Sampling pekerjaan ( Work Sampling )

Work Sampling adalah suatu teknik untuk mengadakan sejumlah besar pengamatan terhadap aktifitas kinerja dari mesin, proses atau pekerja/operator (Sritomo Wignjosoebroto, 2003).

Metode Sampling kerja sangat cocok untuk digunakan dalam melakukan pengamatan atas pekerjaan yang sifatnya tidak berulang dan memiliki siklus waktu yang relatif panjang. Prosedur penggunaannya cukup sederhana, yaitu melakukan pengamatan aktivitas kerja untuk selang waktu yang diambil secara acak terhadap satu atau lebih mesin atau operator dan kemudian mencatatnya apakah mesin atau operator tersebut dalam keadaan bekerja atau menganggur. Sampling pekerjaan memiliki banyak kegunaan dalam dunia industri industri khususnya. Kegunaan-kegunaan dari Sampling Pekerjaan adalah sebagai berikut :

1) Mengetahui distribusi pemakaian waktu sepanjang waktu kerja oleh pekerja atau kelompok kerja.

2) Mengetahui tingkat pemanfaatan mesin-mesin atau alat-alat pabrik.

3) Menentukan waktu baku bagi pekerja-pekerja tidak langsung.

4) Memperkirakan kelonggaran bagi suatu pekerjaan.

\section{Koefisien Tenaga Kerja}

Koefisien analisa harga satuan adalah angka - angka jumlah kebutuhan bahan maupun tenaga yang diperlukan untuk mengerjakan suatu pekerjaan dalam satu satuan tertentu. koefisien analisa harga satuan berfungsi sebagai pedoman awal perhitungan rencana anggaran biaya bangunan, kondisi tersebut membuat koefisien analisa harga satuan menjadi kunci menghitung dengan tepat perkiraan anggaran biaya. Penggunaan tenaga kerja untuk mendapatkan koefisien tenaga kerja dalam satuan jam orang per satuan pengukuran $\left(\mathrm{m}^{1}, \mathrm{~m}^{2}, \mathrm{~m}^{3}\right.$, ton, dll.). Berikut ini rumus yang umum digunakan untuk menentukan koefisien tenaga.

Produksi / hari:

$\mathrm{Qt}=\mathrm{Tk} \times \mathrm{Q} 1$;

Koefisien tenaga $/ \mathrm{m}^{3}$ :

Pekerja $=($ Tk x P $) /$ Qt; Jam

Tukang batu $=(\mathrm{Tk} \times \mathrm{Tb}) / \mathrm{Qt} ; \mathrm{Jam}$

Mandor $=($ Tk x M) / Qt; Jam

Keterangan:

Q1adalah besar kapasitas produksi alat yang menentukan tenaga kerja (jam),

$\mathrm{P}$ adalah jumlah pekerja yang diperlukan (orang),

Tb adalah jumlah tukang batu yang diperlukan (orang),

TK adalah jumlah jam kerja per hari (jam),

$\mathrm{M}$ adalah jumlah mandor yang diperlukan (orang),

\section{METODE PENELITIAN}

Variabel dan Definisi Operasional

Variabel keputusan dapat dinotasikan dengan lambang X. Yang termasuk dalam indikator variabel keputusan dalam penilitian adalah sebagai berikut :

a. Waktu Pelaksanaan Pekerjaan $\left(\mathrm{X}_{1}\right)$

b. Jumlah Pekerjaan $\left(\mathrm{X}_{2}\right)$

c. Harga Sewa Peralatan $\left(\mathrm{X}_{3}\right)$

Variabel keputusan merupakan suatu indikator untuk mencapai variabel tujuan. Yang mana variabel tujuan adalah Harga Perkiraan Sendiri (HPS).

Metode Analisa Data

Metode dalam penelitian ini bersifat kuantitatif dalam menghitung Harga Perkiraan Sendiri (HPS) yang sesuai dalam proses pengadaan barang dan jasa pemeliharaan preventiv penyulang $20 \mathrm{kV}$. 
Berikut ini merupakan flowchart dari penelitian ini.

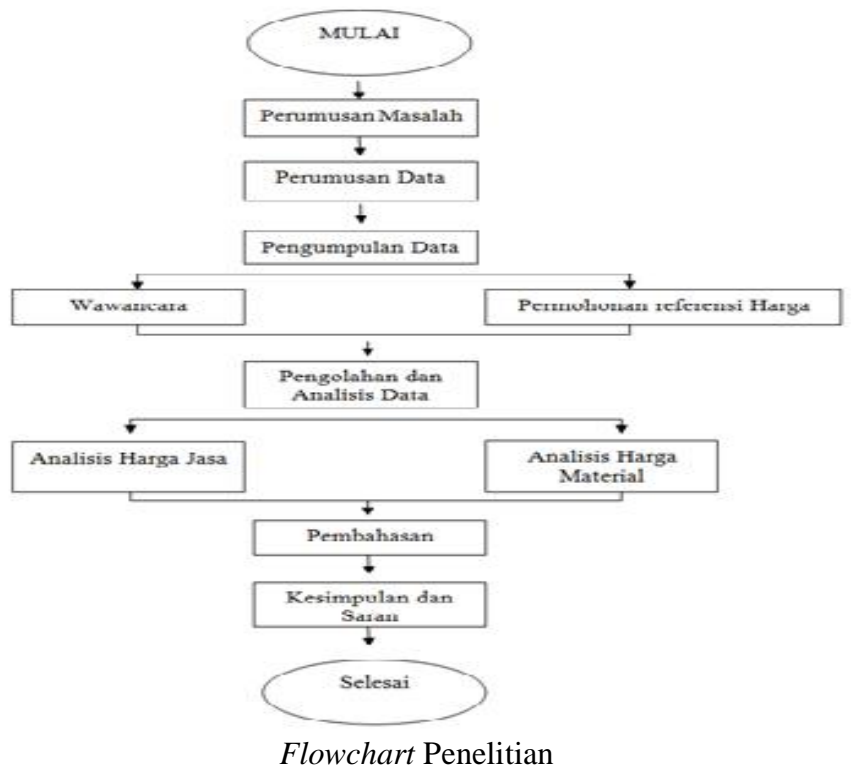

HASIL DAN PEMBAHASAN

Harga Sewa Peralatan K3

Rincian Harga Sewa Peralatan K3

\begin{tabular}{|c|c|c|c|c|c|c|c|c|c|c|}
\hline \multirow{2}{*}{ No. } & \multirow{2}{*}{ Peralatan K3 } & \multirow{2}{*}{ Referensi } & \multirow{2}{*}{ Ongkir } & \multirow{2}{*}{ Harga Beli } & \multirow{2}{*}{ ROK } & \multirow{2}{*}{ HARGA BARANG } & \multicolumn{2}{|c|}{ Masa Pakai } & \multirow{2}{*}{\begin{tabular}{|c} 
Harga Sewa \\
per bulan \\
\end{tabular}} & \multirow{2}{*}{$\begin{array}{c}\text { Harga Sewa } \\
\text { per hari }\end{array}$} \\
\hline & & & & & & & Bulan & Tahun & & \\
\hline 1 & Full Body Harness & 1.350 .000 & 135.000 & 1.485 .000 & 148.500 & 1.633 .500 & 24 & 2 & 68.063 & 2.269 \\
\hline 2 & Sarung Tangan $20 \mathrm{kV}$ & 630.000 & 63.000 & 693.000 & 69.300 & 762.300 & 24 & 2 & 31.763 & 1.059 \\
\hline 3 & Sepatu $20 \mathrm{kV}$ & 2.350 .000 & 235.000 & 2.585 .000 & 258.500 & 2.843 .500 & 24 & 2 & 118.479 & 3.949 \\
\hline 4 & Helm & 200.000 & 20.000 & 220.000 & 22.000 & 242.000 & 12 & 1 & 20.167 & 672 \\
\hline 5 & Sarung Tangan Safety & 150.000 & 15.000 & 165.000 & 16.500 & 181.500 & 12 & 1 & 15.125 & 504 \\
\hline 6 & Sepatu Safety & 450.000 & 45.000 & 495.000 & 49.500 & 544.500 & 12 & 1 & 45.375 & 1.513 \\
\hline 7 & Kacamata Safety & 75.000 & 7.500 & 82.500 & 8.250 & 90.750 & 12 & 1 & 7.563 & 252 \\
\hline 8 & Jas Hujan & 95.000 & 9.500 & 104.500 & 10.450 & 114.950 & 12 & 1 & 9.579 & 319 \\
\hline 9 & Seragam Kerja & 400.000 & 40.000 & 440.000 & 44.000 & 484.000 & 12 & 1 & 40.333 & 1.344 \\
\hline 10 & Sepatu kerja & 450.000 & 45.000 & 495.000 & 49.500 & 544.500 & 12 & 1 & 45.375 & 1.513 \\
\hline 11 & Rompi Safety & 42.000 & 4.200 & 46.200 & 4.620 & 50.820 & 12 & 1 & 4.235 & 141 \\
\hline 12 & Kotak P3K mobil & 30.000 & 3.000 & 33.000 & 3.300 & 36.300 & 12 & 1 & 3.025 & 101 \\
\hline 13 & Papan Peringatan & 380.000 & 38.000 & 418.000 & 41.800 & 459.800 & 60 & 5 & 7.663 & 255 \\
\hline 14 & Apar CO $2 \mathrm{ka}$ & 1.275 .000 & 127.500 & 1.402 .500 & 140.250 & 1.542 .750 & 60 & 5 & 25.713 & 857 \\
\hline
\end{tabular}

Harga Upah Pekerja Dan Perlengkapan Pekerja Lapangan

Rincian Harga Sewa Seragam Dan Peralatan Kerja

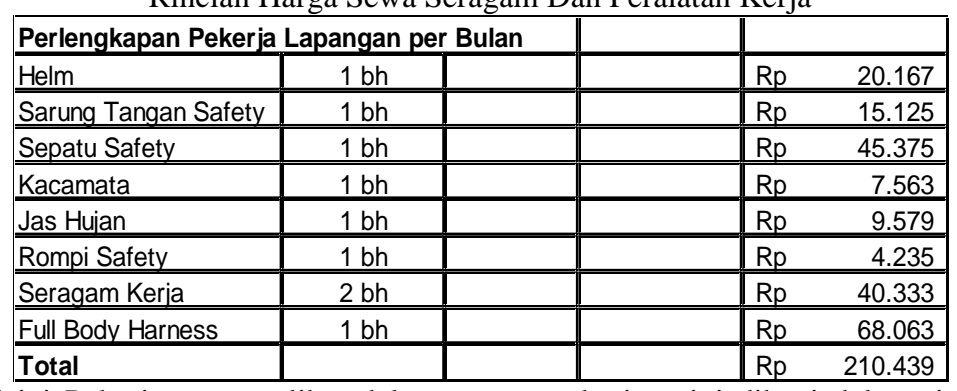

Dalam Hal ini Pekerja yang terlibat dalam proses pekerjaan ini dibagi dalam tiga kategori yaitu pekerja biasa, pekerja berskill atau tukang, dan mandor atau pengawas pekerjaan. Berikut merupakan cara 
dalam menentukan upah tenaga kerjab dengan koefisien pengali sesuai dengan surat edaran General Manajer PT. PLN Wilayah Maluku dan Maluku Utara.

1. Upah Pekerja Ber Skill

Upah Minimum Propinsi Maluku tahun 2017 adalah Rp 1.950.000 (Satu juta Sembilan ratus Lima Puluh Ribu Rupiah) dengan Koefisien pengali adalah 1,4 sesuai dengan surat edaran General Manager Wilayah Maluku dan maluku Utrara No. 006.E/GM.MMU/2016 maka akan didapat upah sebagai berikut:

- $\quad$ Upah Pekerja sebesar 1,4 x $1.950 .000=2.730 .000$

- Jamsostek dan Kesehatan $11.27 \%$ sebesar 2.730 .000 x $11.27 \%=307.671$

- $\quad$ Tunjangan Hari Raya setiap bulannya adalah $1 / 12 \times 2.730 .000=227.500$

- $\quad$ PPH Pasal 21 sebanyak 5\% adalah $5 \%$ x $2.730 .000=163.259$

- $\quad$ APD dan Seragam sebesar 208.700

Maka Total yang Harus Dibayarkan Kepada Pekerja adalah Rp 3.637.130 dalam satu bulan. Untuk mendapatkan upah Harian pekerja maka total Rp 3.637.130 dibagi 21 Hari (Masa Aktif Kerja PLN). Maka akan diperoleh Upah Harian sebesar Rp 3.637.130/21 = 173.197

Perhitungan Tenaga Kerja Berskill

\begin{tabular}{|r|l|r|r|}
\hline No & \multicolumn{1}{|c|}{ UR A I A N } & Satuan & Harga satuan \\
\hline & Pekerja Ber Skill & Orang & 2.730 .000 \\
\hline 1 & Upah 1,4 UMK & Orang & 307.671 \\
\hline 2 & Jamsostek \& Kesehatan 11,27\% & Orang & 227.500 \\
\hline 3 & THR (upah/12) & Orang & 163.259 \\
\hline 5 & PPH Pasal 21 5\%. & Orang & 208.700 \\
\hline 6 & APD \& Seragam & & $\mathbf{3 . 6 3 7 . 1 3 0}$ \\
\hline & Jumlah & & $\mathbf{1 7 3 . 1 9 7}$ \\
\hline & UPAH HARIAN PER ORANG (HO) & &
\end{tabular}

2. Upah Tenaga Kerja Biasa

Upah Minimum Propinsi Maluku tahun 2017 adalah Rp 1.950.000 (Satu juta Sembilan ratus Lima Puluh Ribu Rupiah) dengan Koefisien pengali adalah 1,3 sesuai dengan surat edaran General Manager Wilayah Maluku dan maluku Utrara No. 006.E/GM.MMU/2016 maka akan didapat upah sebagai berikut:

- $\quad$ Upah Pekerja sebesar 1,3 x $1.950 .000=2.535 .000$

- Jamsostek dan Kesehatan $11.27 \%$ sebesar 2.535 .000 x $11.27 \%=285.695$

- $\quad$ Tunjangan Hari Raya setiap bulannya adalah $1 / 12$ x 2.535.000 = 211.250

- $\quad$ PPH Pasal 21 sebanyak 5\% adalah $5 \%$ x 2.535.000 = 151.597

- $\quad$ APD dan Seragam sebesar 208.700

Maka Total yang Harus Dibayarkan Kepada Pekerja adalah Rp 3.392.242 dalam satu bulan. Untuk mendapatkan upah Harian pekerja maka total Rp 3.392.242 dibagi 21 Hari (Masa Aktif Kerja PLN)

Maka akan diperoleh Upah Harian sebesar Rp 3.392.242 /21 = 161.535

Perhitungan Tenaga Kerja Biasa

\begin{tabular}{|c|c|c|c|}
\hline No & URAIAN & Satuan & Harga satuan \\
\hline & \multicolumn{3}{|l|}{ Pekerja Biasa } \\
\hline 1 & Upah 1,3 UMK & Orang & 2.535 .000 \\
\hline 2 & Jamsostek \& Kesehatan 11,27 \% & Orang & 285.695 \\
\hline 3 & THR (upah/12) & Orang & 211.250 \\
\hline 5 & PPH Pasal 21 5\%. & Orang & 151.597 \\
\hline 6 & APD \& Seragam & Orang & 208.700 \\
\hline & Jumlah & & 3.392 .242 \\
\hline & UPAH HARIAN PER ORANG (HO) & & 161.535 \\
\hline
\end{tabular}

3. Upah Mandor Atau Tenaga Mandor

Upah Minimum Propinsi Maluku tahun 2017 adalah Rp 1.950.000 (Satu juta Sembilan ratus Lima Puluh Ribu Rupiah) dengan Koefisien pengali adalah 1,45 sesuai dengan surat edaran General Manager Wilayah Maluku dan maluku Utrara No. 006.E/GM.MMU/2016 maka akan didapat upah sebagai berikut:

- $\quad$ Upah Pekerja sebesar 1,3 x $1.950 .000=2.827 .500$

- Jamsostek dan Kesehatan $11.27 \%$ sebesar 2.827 .500 x $11.27 \%=318.659$

- $\quad$ Tunjangan Hari Raya setiap bulannya adalah $1 / 12$ x 2.827.500 = 235.625

- $\quad$ PPH Pasal 21 sebanyak 5\% adalah 5\% x 2.827.500 = 169.089 
- $\quad$ APD dan Seragam sebesar 208.700

Maka Total yang Harus Dibayarkan Kepada Pekerja adalah Rp 3.692.073 dalam satu bulan. Untuk mendapatkan upah Harian pekerja maka total Rp 3.692.073 dibagi 21 Hari (Masa Aktif Kerja PLN) Maka akan diperoleh Upah Harian sebesar Rp 3.692.073 /21 = 175.813

PerhitunganMandor atau Tenaga Pengawas

\begin{tabular}{|c|c|c|c|}
\hline No & URAIAN & Satuan & Harga satuan \\
\hline & \multicolumn{3}{|l|}{ Mandor } \\
\hline 1 & Upah 1.45 UMK & Orang & 2.827 .500 \\
\hline 2 & Jamsostek \& Kesehatan 11,27\% & Orang & 318.659 \\
\hline 3 & THR (upah/12) & Orang & 235.625 \\
\hline 5 & PPH Pasal 21 5\%. & Orang & 169.089 \\
\hline 6 & APD \& Seragam & Orang & 141.200 \\
\hline & Jumlah & & 3.692 .073 \\
\hline & UPAH HARIAN PER ORANG ( HO) & & 175.813 \\
\hline
\end{tabular}

\section{Menentukan Harga Sewa Peralatan Kerja Dalam Hari}

Perhitungan Biaya Sewa Peralatan

\begin{tabular}{|c|c|c|c|c|c|c|c|c|c|c|}
\hline \multirow{2}{*}{ №. } & \multirow{2}{*}{ Peralatan Kerja } & \multirow{2}{*}{ Referensi } & \multirow{2}{*}{ Ongkir } & \multirow{2}{*}{ Harga Beli } & \multirow{2}{*}{ ROK $10 \%$} & \multirow{2}{*}{ TOTAL HARGA } & \multicolumn{2}{|c|}{ Masa Pakai } & \multirow{2}{*}{\begin{tabular}{c|} 
Harga Sewa \\
per bulan
\end{tabular}} & \multirow{2}{*}{$\frac{\text { Harga Sewa }}{\text { per hari }}$} \\
\hline & & & & & & & Bulan & Tahun & & \\
\hline 1 & Tang Ampere Digital (True RMS) Dig 600 A & 1.150 .000 & 100.000 & 1.250 .000 & 125.000 & 1.375 .000 & 36 & 3 & 38.194 & 1.273 \\
\hline 2 & Phasa Meter & 700.000 & 100.000 & 800.000 & 80.000 & 880.000 & 36 & 3 & 24.444 & 815 \\
\hline 3 & Ratchet Puller 2 ton + comelong & 2.450 .000 & 350.000 & 2.800 .000 & 280.000 & 3.080 .000 & 36 & 3 & 85.556 & 2.852 \\
\hline 4 & Tangga fiber $12 \mathrm{mtr} 2$ section & 11.957 .800 & 2.500 .000 & 14.457 .800 & 1.445 .780 & 15.903 .580 & 36 & 3 & 441.766 & 14.726 \\
\hline 5 & Hot stick 20 kV 12 meter & 7.800 .000 & 500.000 & 8.300 .000 & 830.000 & 9.130 .000 & 36 & 3 & 253.611 & 8.454 \\
\hline 6 & Tool set & 2.460 .000 & 350.000 & 2.810 .000 & 281.000 & 3.091 .000 & 36 & 3 & 85.861 & 2.862 \\
\hline 7 & Teropong & 199.000 & 50.000 & 249.000 & 24.900 & 273.900 & 36 & 3 & 7.608 & 254 \\
\hline 8 & Kamera & 4.350 .000 & 58.000 & 4.408 .000 & 440.800 & 4.848 .800 & 36 & 3 & 134.689 & 4.490 \\
\hline 9 & Gergaj kayu + Stick & 396.000 & 500.000 & 896.000 & 89.600 & 985.600 & 24 & 2 & 41.067 & 1.369 \\
\hline 10 & Gergaji mesin & 2.850 .000 & 500.000 & 3.350 .000 & 335.000 & 3.685 .000 & 60 & 5 & 61.417 & 2.047 \\
\hline 11 & Lampu Senter Rechargeable & 350.000 & 50.000 & 400.000 & 40.000 & 440.000 & 12 & 1 & 36.667 & 1.222 \\
\hline 12 & Sockley Lamp $12 \mathrm{~V}, 55 \mathrm{~W}$ dengan soket & 450.000 & 100.000 & 550.000 & 55.000 & 605.000 & 36 & 3 & 16.806 & 560 \\
\hline 13 & Komputer \& Printer & 8.275 .000 & & 8.275 .000 & 827.500 & 9.102 .500 & 60 & 5 & 151.708 & 5.057 \\
\hline 14 & Kuas kecil & 7.000 & & 7.000 & 700 & 7.700 & 1 & & 7.700 & 257 \\
\hline 15 & Radio HT Dualband & 2.900 .000 & 100.000 & 3.000 .000 & 300.000 & 3.300 .000 & 36 & 3 & 91.667 & 3.056 \\
\hline 16 & Radio Base station ,kabel,antena,bracket & 4.960 .000 & 150.000 & 5.110 .000 & 511.000 & 5.621 .000 & 36 & 3 & 156.139 & 5.205 \\
\hline 17 & ATK & 17.000 & & 17.000 & 1.700 & 18.700 & 1 & & 18.707 & 624 \\
\hline 18 & Grounding Set & 13.750 .000 & 500.000 & 14.250 .000 & 1.425 .000 & 15.675 .000 & 36 & 3 & 435.417 & 14.514 \\
\hline 19 & Tang Press $10-70 \mathrm{~mm}$ & 685.000 & 200.000 & 885.000 & 88.500 & 973.500 & 36 & 3 & 27.042 & 901 \\
\hline 20 & Tang Press $70-300 \mathrm{~mm}$ & 3.500 .000 & 300.000 & 3.800 .000 & 380.000 & 4.180 .000 & 36 & 3 & 116.111 & 3.870 \\
\hline 21 & GPS Garmin Oregon 650 & 5.300 .000 & 50.000 & 5.350 .000 & 535.000 & 5.885 .000 & 36 & 3 & 163.472 & 5.449 \\
\hline 22 & Tangga lipat 2,6 meter & 1.334 .300 & 850.000 & 2.184 .300 & 218.430 & 2.402 .730 & 36 & 3 & 66.743 & 2.225 \\
\hline 23 & Tali manila $12 \mathrm{~mm}^{2} 20 \mathrm{mtr}$ & 90.000 & 100.000 & 190.000 & 19.000 & 209.000 & 12 & 1 & 17.417 & 581 \\
\hline 24 & Gunting kabel $240 \mathrm{~mm}$ & 550.000 & 100.000 & 650.000 & 65.000 & 715.000 & 36 & 3 & 19.861 & 662 \\
\hline 25 & Parang & 92.000 & & 92.000 & 9.200 & 101.200 & 12 & 1 & 8.433 & 281 \\
\hline 26 & Palu $5 \mathrm{~kg}$ & 150.000 & & 150.000 & 15.000 & 165.000 & 36 & 3 & 4.583 & 153 \\
\hline 27 & Gergaji besi & 194.000 & & 194.000 & 19.400 & 213.400 & 36 & 3 & 5.928 & 198 \\
\hline 28 & Voltage Detector $20 \mathrm{kV}$ & 3.577 .119 & 400.000 & 3.977 .119 & 397.712 & 4.374 .831 & 36 & 3 & 121.523 & 4.051 \\
\hline 29 & Almari Peralatan minimal 23" & 365.000 & 200.000 & 565.000 & 56.500 & 621.500 & 36 & 3 & 17.264 & 575 \\
\hline 30 & Kaki Tiga & 14.051 .520 & & 14.051 .520 & 1.405 .152 & 15.456 .672 & 24 & 2 & 644.028 & 21.468 \\
\hline 31 & Sekop & 65.000 & & 65.000 & 6.500 & 71.500 & 12 & 1 & 5.958 & 199 \\
\hline 32 & Linggis & 75.000 & & 75.000 & 7.500 & 82.500 & 12 & 1 & 6.875 & 229 \\
\hline 33 & Cangkul & 65.000 & & 65.000 & 6.500 & 71.500 & 12 & 1 & 5.958 & 199 \\
\hline 34 & Teakel / Chain Blok & 4.100 .000 & & 4.100 .000 & 410.000 & 4.510 .000 & 24 & 2 & 187.917 & 6.264 \\
\hline 35 & Ratchet Obeng & 225.000 & & 225.000 & 22.500 & 247.500 & 12 & 1 & 20.625 & 688 \\
\hline 36 & Besi UNP 103 meter & 1.375 .000 & & 1.375 .000 & 137.500 & 1.512 .500 & 36 & 3 & 42.014 & 1.400 \\
\hline
\end{tabular}




\section{Daftar Harga Sewa Peralatan Kerja}

Perhitungan Biaya Sewa Peralatan Dalam Uraian Pekerjaan

\begin{tabular}{|c|c|c|c|c|c|}
\hline \multirow{2}{*}{\begin{tabular}{|l|} 
Nama Pekerjaan \\
JTM \\
\end{tabular}} & \multirow{2}{*}{$\begin{array}{c}\text { Peralatan Yang } \\
\text { Digunakan }\end{array}$} & \multirow{2}{*}{ Volume } & \multirow{2}{*}{$\begin{array}{c}\text { Harga Sewa } \\
\text { per Hari }\end{array}$} & \multirow{2}{*}{ Jumlah } & \multirow{2}{*}{ Total } \\
\hline & & & & & \\
\hline \multirow[t]{7}{*}{ Penanaman Tiang } & & & & & 29.137 \\
\hline & Sekop & 2 & 199 & 397 & \\
\hline & Linggis & 1 & 229 & 229 & \\
\hline & Kaki Tiga & 1 & 21.468 & 21.468 & \\
\hline & Chain Blok & 1 & 6.264 & 6.264 & \\
\hline & Cangkul & 1 & 199 & 199 & \\
\hline & Tali Tampar & 1 & 581 & 581 & \\
\hline \multirow[t]{6}{*}{ Pemasangan Assesoris } & & & & - & 41.136 \\
\hline & Tangga Fiber & 1 & 14.726 & 14.726 & \\
\hline & Tali Tampar & 1 & 581 & 581 & \\
\hline & Tool Set & 1 & 2.862 & 2.862 & \\
\hline & Hot Stick $20 \mathrm{kV}$ & 1 & 8.454 & 8.454 & \\
\hline & \begin{tabular}{|l} 
Grounding Stick \\
\end{tabular} & 1 & 14.514 & 14.514 & \\
\hline \multirow[t]{7}{*}{ Penarikan Konduktor } & & & & - & 59.294 \\
\hline & Tangga Fiber & 2 & 14.726 & 29.451 & \\
\hline & Tali Tampar & 2 & 581 & 1.161 & \\
\hline & Tool Set & 1 & 2.862 & 2.862 & \\
\hline & Puller + Comealong & 1 & 2.852 & 2.852 & \\
\hline & Hot Stick $20 \mathrm{kV}$ & 1 & 8.454 & 8.454 & \\
\hline & Grounding Stick & 1 & 14.514 & 14.514 & \\
\hline Pembuatan Jointhing & & & & - & 7.313 \\
\hline & Tali Tampar & 1 & 581 & 581 & \\
\hline & Tool Set & 1 & 2.862 & 2.862 & \\
\hline & Tang Press & 1 & 3.870 & 3.870 & \\
\hline Pemasangan Skun Kabel & & & & & 22.039 \\
\hline & Tali Tampar & 1 & 581 & 581 & \\
\hline & Tool Set & 1 & 2.862 & 2.862 & \\
\hline & Tang Press & 1 & 3.870 & 3.870 & \\
\hline & Tangga Fiber & 1 & 14.726 & 14.726 & \\
\hline Penanaman Arde / Beton Block & & & & - & 3.488 \\
\hline & Sekop & 1 & 199 & 199 & \\
\hline & Linggis & 1 & 229 & 229 & \\
\hline & Cangkul & 1 & 199 & 199 & \\
\hline & Tool Set & 1 & 2.862 & 2.862 & \\
\hline Pembuatan Lubang & & & & & \\
\hline & Linggis & 2 & 229 & 458 & 856 \\
\hline & Cangkul & 1 & 199 & 199 & \\
\hline & Sekop & 1 & 199 & 199 & \\
\hline K2/K3 Umum & Satuan & Volume & $\begin{array}{c}\text { Harga Sewa } \\
\text { Per Hari }\end{array}$ & Jumlah & Total \\
\hline & & & & & 1.203 \\
\hline Apar CO & $\mathrm{bh}$ & 1 & 850 & 850 & \\
\hline P3K Mobil & bh & 1 & 100 & 100 & \\
\hline Plat tanda Bahaya & bh & 1 & 253 & 253 & \\
\hline
\end{tabular}

\section{Menentukan Harga Perkiraan Sendiri (Jasa)}

Harga Perkiraan Sendiri Untuk Jasa

\begin{tabular}{|c|c|c|c|c|c|c|c|c|c|c|c|c|c|c|c|c|c|c|c|c|c|}
\hline \multicolumn{22}{|c|}{ ANALISA HARG SATUAN JASA } \\
\hline URAAANP & VOL & SAT & $\begin{array}{l}\text { Waktu Pekerjaan } \\
\text { (Menit) }\end{array}$ & \begin{tabular}{|c|} 
Qt \\
(hasi/haril)
\end{tabular} & $\begin{array}{c}1 \\
\text { Qsatuan/i }\end{array}$ & $\begin{array}{l}\text { Jumlah } \\
\text { Tenaga }\end{array}$ & $\begin{array}{c}p \\
\text { Org }\end{array}$ & & $\bar{M}$ & Tk & QMandor & $\begin{array}{c}Q \\
\text { Tukang }\end{array}$ & $\begin{array}{c}\text { Q } \\
\text { Pekeria }\end{array}$ & Upahm & UpahT & Upahp & Total SDM & ROK & \begin{tabular}{l|l} 
Sewa \\
Alat
\end{tabular} & \begin{tabular}{|c|} 
Sewa \\
33
\end{tabular} & JASA PASANG \\
\hline Tiang Besi 11 meter 156 dAN & 1 & bh & 24 & 20,00 & 2,50 & 7 & 5 & 1 & 1 & 8 & 0,02 & 0,40 & 2,000 & 3.517 & 69.312 & 323.236 & 396.065 & 39.606 & 1.457 & 61 & 437.189 \\
\hline Tiang Besi 11 meter 156 dAN (sL & 1 & bh & 30 & 16,00 & 2,00 & 7 & 5 & 1 & 1 & 8 & 0,03 & 0,50 & 2,5 & 4.397 & 86.640 & 404.045 & 495.081 & 49.508 & 1.821 & 76 & 546.486 \\
\hline Tiang Besi 11 meter $200 \mathrm{dAN}$ & 1 & bh & 25 & 19,20 & 2,40 & 7 & 5 & 1 & 1 & 8 & 0,02 & 0,42 & 2,08 & 3.664 & 72.200 & 336.704 & 412.568 & 41.257 & 1.518 & 63 & 455.405 \\
\hline Tiang Besi 11 meter 200 dAN (sulit) & 1 & bh & 32 & 5,00 & 1,88 & 7 & 5 & 1 & 1 & 8 & 0,03 & 0,53 & 2,67 & 4.690 & 92.415 & 30.981 & 28.087 & 52.809 & 1.942 & 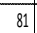 & 82.919 \\
\hline Tiang Besi 11 meter 350 dAN & 1 & bh & 27 & 17,78 & 2,22 & 7 & 5 & 1 & 1 & 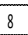 & 0,02 & 0,45 & 2,25 & 3.957 & 77.976 & 363.641 & 445.573 & 44.557 & 1.639 & 68 & 491.838 \\
\hline Tiang Besi 11 meter 350 dAN (sulit) & 1 & bh & 35 & 13,71 & 1,71 & 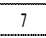 & 5 & 1 & 1 & 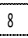 & 0,03 & 0,58 & 2,92 & 5.130 & 101.079 & 471.386 & 577.595 & 57.759 & 2.125 & 88 & 637.567 \\
\hline Tiang Besi 12 meter 140 dAN & 1 & bh & 27 & 17,78 & 2,22 & 7 & 5 & 1 & 1 & 8 & 0,02 & 0,45 & 2,25 & 3.957 & 77.976 & 363.641 & 445.573 & 44.557 & 1.639 & 68 & 491.838 \\
\hline Tiang Besi 12 meter 140 dAN (sulit) & 1 & bh & 35 & 13,71 & 1,71 & 7 & 5 & 1 & 1 & 8 & 0,03 & 0,58 & 2,92 & 5.130 & 101.079 & 471.386 & 577.595 & 57.759 & 2.125 & 88 & 637.567 \\
\hline Tiang Besi 12 meter 200 dAN & 1 & bh & 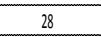 & 17,14 & 2,14 & 7 & 5 & 1 & 1 & 8 & 0,02 & 0,47 & 2,33 & 4.104 & 80.864 & 377.109 & 462.076 & 46.208 & 1.700 & 71 & 510.054 \\
\hline Tiang Besi 12 meter 200 dAN (sulit) & 1 & bh & 35 & 13,71 & 1,71 & 7 & 5 & 1 & 1 & 8 & 0,03 & 0,58 & 2,92 & 5.130 & 101.079 & 471.386 & 577.595 & 57.759 & 2.125 & 88 & 637.567 \\
\hline Tiang Besi 12 meter $350 \mathrm{dAN}$ & 1 & bh & 32 & 15,00 & 1,88 & 7 & 5 & 1 & 1 & 8 & 0,03 & 0,53 & 2,67 & 4.690 & 92.415 & 430.981 & 528.087 & 52.809 & 1.942 & 81 & 582.919 \\
\hline Tiang Besi 12 meter 350 dAN (sulit) & 1 & bh & 40 & 12,00 & 1,50 & 7 & 5 & 1 & 1 & 8 & 0,03 & 0,67 & 3,33 & 5.862 & 115.519 & 538.727 & 660.108 & 66.011 & 2.428 & 101 & 728.648 \\
\hline Tiang Besi 13 meter 200 dAN & 1 & bh & 33 & 14,55 & 1,82 & 7 & 5 & 1 & 1 & 8 & 0,03 & 0,55 & 2,75 & 4.836 & 95.303 & 444.450 & 544.589 & 54.459 & 2.003 & 83 & 601.135 \\
\hline Tiang Besi 13 meter 200 dAN (sulit) & 1 & bh & 45 & 10,67 & 1,33 & 7 & 5 & 1 & 1 & 8 & 0,04 & 0,75 & 3,75 & 6.595 & 129.959 & 606.068 & 742.622 & 74.262 & 2.732 & 114 & 819.729 \\
\hline Tiang Besi 13 meter 350 dAN & 1 & bh & 35 & 13,71 & 1,71 & 7 & 5 & 1 & 1 & 8 & 0,03 & 0,58 & 2,92 & 5.130 & 101.079 & 471.386 & 577.595 & 57.759 & 2.125 & 88 & 637.567 \\
\hline Tiang Besi 13 meter 350 dAN (sulit) & 1 & bh & 40 & 12,00 & 1,50 & 7 & 5 & 1 & 1 & 8 & 0,03 & 0,67 & 3,33 & 5.862 & 115.519 & 538.727 & 660.108 & 66.011 & 2.428 & 101 & 728.648 \\
\hline Tiang Besi 14 meter & 1 & bh & 48 & 10,00 & 1,25 & 7 & 5 & 1 & 1 & 8 & 0,04 & 0,80 & 4,00 & 7.035 & 138.623 & 646.472 & 792.130 & 79.213 & 2.914 & 121 & 874.378 \\
\hline Tiang Besi 14 meter (sulit) & 1 & bh & 60 & 8,00 & 1,00 & 7 & 5 & 1 & 1 & 8 & 0,05 & 1,00 & 5,00 & 8.793 & 173.279 & 808.090 & 990.162 & 99.016 & 3.642 & 152 & 1.092 .972 \\
\hline Tiang Besi 9 meter 156 daN & 1 & bh & 18 & 26,67 & 3,33 & 7 & 5 & 1 & 1 & 8 & 0,02 & 0,30 & 1,50 & 2.638 & 51.984 & 242.427 & 297.049 & 29.705 & 1.093 & 46 & 327.892 \\
\hline Tiang Besi 9 meter 156 daN (sullit) & 1 & bh & 25 & 19,20 & 2,40 & 7 & 5 & 1 & 1 & 8 & 0,02 & 0,42 & 2,08 & 3.664 & 72.200 & 336.704 & 412.568 & 41.257 & 1.518 & 63 & 455.405 \\
\hline Tiang Bes 9 meter 200 daN & 1 & bh & 18 & 26,67 & 3,33 & 7 & 5 & 1 & 1 & 8 & 0,02 & 0,30 & 1,50 & 2.638 & 51.984 & 242.427 & 297.049 & 29.705 & 1.093 & 46 & 327.892 \\
\hline Tiang Besi 9 meter 200 daN (sulit) & 1 & bh & 27 & 17,78 & 2,22 & 7 & 5 & 1 & 1 & 8 & 0,02 & 0,45 & 2,25 & 3.957 & 77.976 & 363.641 & 445.573 & 44.557 & 1.639 & 68 & 491.838 \\
\hline Pembuatan Lubang Tiang & 1 & bh & 60 & 8,00 & 1,00 & 3 & 2 & 0 & 1 & 8 & 0,05 & 0,00 & 2,00 & 8.793 & . & 323.236 & 332.029 & 33.203 & 107 & 152 & 365.491 \\
\hline Pembuatan Lubang Tiang (Sulit) & 1 & bh & 90 & 5,33 & 0,67 & 3 & 2 & 0 & 1 & 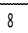 & 0,08 & 0,00 & 3,00 & 13.190 & & 484.854 & 498.044 & 49.804 & - & 228 & 548.076 \\
\hline
\end{tabular}




\section{Menentukan Harga Perkiraan Sendiri (Material)}

1. Harga Barang Dengan Loko On Site

Perhitungan HPS Untuk Material Dengan Referensi Loko On Site

\begin{tabular}{|c|c|c|c|c|c|c|c|}
\hline NAMA MATERIAL & SATUAN & $\begin{array}{l}\text { QUANT } \\
\text { ITY (Q) }\end{array}$ & \multicolumn{2}{|c|}{ NAMA PENYEDIA } & $\begin{array}{c}\text { HARGA YANG } \\
\text { DI PAKAI }\end{array}$ & ROK & HARGA HPS \\
\hline & & & $\begin{array}{c}\text { PT. SINAR JAYA } \\
\text { ELEKTRINDO }\end{array}$ & $\begin{array}{c}\text { PT. TRILLSTRINDO } \\
\text { PRATAMA }\end{array}$ & & & \\
\hline 1 Termination Indoor 1C, 70 - 120 mm2 & set & 1 & 2.750 .000 & 2.376 .000 & 2.376 .000 & 237.600 & 2.613 .600 \\
\hline 2 Termination Indoor 1C, $150-300 \mathrm{~mm} 2$ & set & 1 & 4.100 .000 & 4.027 .875 & 4.027 .875 & 402.788 & 4.430 .663 \\
\hline 3 Termination Outdoor 1C, $70-120 \mathrm{~mm} 2$ & set & 1 & 3.600 .000 & 2.864 .575 & 2.864 .575 & 286.458 & 3.151 .033 \\
\hline 4 Termination Outdoor 1C, $150-300 \mathrm{~mm} 2$ & set & 1 & 4.350 .000 & 4.146 .950 & 4.146 .950 & 414.695 & 4.561 .645 \\
\hline 5 Termination Indoor 3C, $70-120 \mathrm{~mm} 2$ & set & 1 & 4.800 .000 & 3.819 .750 & 3.819 .750 & 381.975 & 4.201 .725 \\
\hline 6 Termination Indoor 3C, 150 - $240 \mathrm{~mm} 2$ & set & 1 & 5.750 .000 & 4.631 .750 & 4.631 .750 & 463.175 & 5.094 .925 \\
\hline 7 Termination Outdoor 3C, $70-120 \mathrm{~mm} 2$ & set & 1 & 5.500 .000 & 4.170 .825 & 4.170 .825 & 417.083 & 4.587 .908 \\
\hline 8 Termination Outdoor 3C, 150 - $240 \mathrm{~mm} 2$ & set & 1 & 6.850 .000 & 5.232 .075 & 5.232 .075 & 523.208 & 5.755 .283 \\
\hline 9 Jointing Cable 1C,70-95 mm2 & set & 1 & 5.750 .000 & 4.523 .390 & 4.523 .390 & 452.339 & 4.975 .729 \\
\hline 10 Jointing Cable 1C, 120 - $185 \mathrm{~mm} 2$ & set & 1 & 6.500 .000 & 5.944 .440 & 5.944 .440 & 594.444 & 6.538 .884 \\
\hline 11 Jointing Cable 1C, $150-240 \mathrm{~mm} 2$ & set & 1 & 6.850 .000 & 6.623 .350 & 6.623 .350 & 662.335 & 7.285 .685 \\
\hline 12 Jointing Cable 3C, $70-95 \mathrm{~mm} 2$ & set & 1 & 6.850 .000 & 5.210 .890 & 5.210 .890 & 521.089 & 5.731 .979 \\
\hline 13 Jointing Cable 3C, 120 - $185 \mathrm{~mm} 2$ & set & 1 & 7.200 .000 & 6.425 .690 & 6.425 .690 & 642.569 & 7.068 .259 \\
\hline 14 Jointing Cable 3C, 150 - $240 \mathrm{~mm} 2$ & set & 1 & 7.450 .000 & 6.967 .100 & 6.967 .100 & 696.710 & 7.663 .810 \\
\hline
\end{tabular}

Berdasarkan tabel diatas harga yang dipakai adalah harga penawaran terendah dari referensi yang diterima karna mengacu salah satu syarat pengadaan yaitu ekonomis, mendapatkan harga serendahrendahnya dengan mutu yang sabaik-baiknya. Dikarenakan di dalam referensi harga tersebut barang yang di tawarkan belom di kenakan pajak maka dalam pembuatan HPS harus di tambahkan pajak sebesar $10 \%$ (sepuluh persen). Risk, Overhead dan Keuntungan (ROK) adalah keuntungan untuk calon penyedia barang dan jasa lain dan biaya tak terduga yang sering muncul di dalam proses pengadaan barang dan jasa, ROK yang penulis pakai adalah sebesar $10 \%$ mengacu pada ROK maksimal yang di pakai oleh PT. PLN (Persero) Area Ambon.

\section{Harga Barang Dengan Loko Pabrkan}

Perhitungan HPS Untuk Material Dengan Referensi Loko On Site

\begin{tabular}{|c|c|c|c|c|c|c|c|c|c|c|}
\hline \multirow[t]{2}{*}{ NO } & \multirow[t]{2}{*}{ NAMA MATERIAL } & \multirow[t]{2}{*}{ SATUAN } & \multirow[t]{2}{*}{$\begin{array}{l}\text { QUANT } \\
\text { ITY (Q) }\end{array}$} & \multicolumn{2}{|c|}{ NAMA PENYEDIA } & \multirow[t]{2}{*}{$\begin{array}{c}\text { HARGA YANG } \\
\text { DI PAKAI }\end{array}$} & \multirow[t]{2}{*}{ ONGKIR } & \multirow[t]{2}{*}{$\begin{array}{c}\text { JUMLAH + } \\
\text { ONGKIR }\end{array}$} & \multirow[t]{2}{*}{ ROK } & \multirow[t]{2}{*}{ HARGA HPS } \\
\hline & & & & $\begin{array}{l}\text { PT. VOKSEL } \\
\text { ELEKTRIC }\end{array}$ & $\begin{array}{l}\text { PT. PRIMA CABLE } \\
\text { LINDO }\end{array}$ & & & & & \\
\hline & 1 1 Kabel NYY $1 \times 70 \mathrm{~mm}^{2}$ & $\mathrm{mtr}$ & 1 & 102.300 & 94.668 & 94.668 & 4.733 & 99.401 & 9.940 & 109.342 \\
\hline & 2Kabel NYY 1 X 150 mm² & mtr & 1 & 222.100 & 196.098 & 196.098 & 9.805 & 205.903 & 20.590 & 226.493 \\
\hline & 3 Kabel NYY 1 x 240 mm² & mtr & 1 & 354.700 & 326.266 & 326.266 & 16.313 & 342.579 & 34.258 & 376.837 \\
\hline & 4 Kawat AAAC - $70 \mathrm{~mm}^{2}$ & mtr & 1 & 13.300 & 10.580 & 10.580 & 529 & 11.109 & 1.111 & 12.220 \\
\hline & 5 Kawat AAAC - S $150 \mathrm{~mm}^{2}$ & $m$ mtr & 1 & 27.600 & 27.100 & 27.100 & 1.355 & 28.455 & 2.846 & 31.301 \\
\hline & & & & \begin{tabular}{|c|} 
PT. BHUMI \\
RAYA PERKASA
\end{tabular} & PT.SINARINDO & & & & & \\
\hline & 1 Sepatu Cable CU 35 & bh & 1 & 39.000 & 30.800 & 30.800 & 1.540 & 32.340 & 3.234 & 35.574 \\
\hline & 2 Sepatu Cable CU 50 & bh & 1 & 44.000 & 46.350 & 44.000 & 2.200 & 46.200 & 4.620 & 50.820 \\
\hline & 3 Sepatu Cable CU 70 & bh & 1 & 58.000 & 63.250 & 58.000 & 2.900 & 60.900 & 6.090 & 66.990 \\
\hline & 4 Sepatu Cable CU 95 & bh & 1 & 72.000 & 80.300 & 72.000 & 3.600 & 75.600 & 7.560 & 83.160 \\
\hline & 5 Sepatu Cable CU 120 & bh & 1 & 86.000 & 102.300 & 86.000 & 4.300 & 90.300 & 9.030 & 99.330 \\
\hline & 6 Sepatu Cable CU 150 & bh & 1 & 125.000 & 133.100 & 125.000 & 6.250 & 131.250 & 13.125 & 144.375 \\
\hline
\end{tabular}


Berdasarkan tabel diatas harga Perhitungan Harga Perkiraan Sendiri (HPS) adalah Harga Referensi terendah yang di terima dari beberapa referensi harga kemudian di tambahkan Ongkos Kirim dan setelahnya di tambahkan ROK sebagai Keuntungan maupun biaya lain-lain yang tak terduga. Berdasarkan table diatas dapat kita peroleh untuk HPS material kabel NYY 1x70 mm2 adalah sebesar Rp 109.342 ribu rupiah, dan Harga HPS untuk material sepatu kabel CU 35 mm adalah sebesar Rp 35.574 ribu rupiah.

\section{KESIMPULAN}

1. Penentuan Harga Perkiraan Sendiri (HPS) untuk Pekerjaan pengadaan Barang dan Jasa Pemeliharaan Preventif Penyulang 20 kV di PT. PLN (Persero) Wilayah Maluku dan maluku Utara Area Ambon dapat diperoleh dengan pola sebagai berikut:

A. HPS Jasa = ( Analisa Harga Satuan + Analasia Harga Sewa Peralatan dan K3 + ROK $)$

B. HPS Material untuk harga material dengan referensi Loko Ambon $=($ Harga referensi + ROK $)$ HPS Material

C. HPS Material untuk harga material dengan referensi Loko Pabrikan $=($ Harga Referensi + Estimasi Ongkir + ROK)

2. Berdasarkan metode diatas dapat diperoleh untuk harga Jasa Pemasangan Tiang Besi 156 DAN adalah sebesar Rp 436.969,00 sedangkan untuk Tiang Besi 156 DAN untuk kategori daerah yang sulit adalah sebesar Rp 546.211,00

\section{DAFTAR PUSTAKA}

Sutalaksana, I. Z., Anggawisastra, R., \& Tjakraatmadja, J. H. (2006). Teknik perancangan sistem kerja. Bandung: ITB.

.Kementrian Pekerjaan Umum.(2013).Peraturan Menteri Pekerjaan Umum Republik Indonesia Nomor 11/PRT/M/2013 tentang pedoman analisis harga satuan pekerjaan bidang pekerjaan umum.Jakarta

.PT.PLN (Persero).(2016).Edaran Direksi PT.PLN (Persero) nomor 010.E/DIR/2016 tentang Petunjuk Teknis Pengadaan Barang/Jasa PT. PLN (Persero).

.PT.PLN (Persero).(2014). Peraturan Direksi PT.PLN (Persero) nomor 0527.K/DIR/2014 tentang Perubahan Atas Keputusan Direksi PT.PLN (Persero) nomor 0620.K/DIR/2013 tentang Pedoman Umum Pengadaan Barang/Jasa PT. PLN (persero).

.PT.PLN (Persero).(2014).Edaran Direksi PT.PLN (Persero) nomor 0014.E/DIR/2014 tentang Perubahan Edaran Direksi PT. PLN (Persero) nomor 003.E/DIR/2014 tentang Petunjuk Teknis Pengadaan Barang/Jasa PT. PLN (Persero).

.PT.PLN (Persero).(2013).Keputusan Direksi PT.PLN (Persero) nomor 0620.K/DIR/2013 tentang Pedoman Umum Pengadaan Barang/Jasa PT. PLN (Persero).

.Republik Indonesia.(2015). peraturan presiden republik indonesia nomor 4 tahun 2015 perubahan ke empat atas peraturan presiden nomor 54 tahun 2010 tentang pengadaan barang/jasa pemerintah, Sekertaris kabinet RI. Jakarta.

Purwanto, D. (2017).: Aplikasi Penentuan Harga Perkiraan Sendiri Proyek Pengembangan Perangkat Lunak Kepemerintahan Berbasis Web , Tugas Akhir, Institut Bisnis dan Informatika Stikom Surabaya

Wignjosoebroto, S. (2003). Pengantar teknik dan manajemen industri. Surabaya: Guna Widya.

Widodo, A. P., Sutanto, T., \& Sholiq, S. (2016). LP: Pembuatan Kerangka Kerja Penentuan Harga Perkiraan Sendiri (HPS) untuk Proyek Pengembangan Perangkat Lunak Kepemerintahan dengan Pendekatan Use Case Point.

WK Consulting.(2016).Teknik dan Metode Penyusunan HPS.Ambon 